\title{
Treatment of fishpond water by recirculating horizontal and vertical flow constructed wetlands in the tropics
}

\author{
Dennis Konnerup a,*, Ngo Thuy Diem Trang ${ }^{\mathrm{b}}$, Hans Brix ${ }^{\mathrm{a}}$ \\ a Department of Biological Sciences, Plant Biology, Aarhus University, Ole Worms Allé 1, DK-8000 Aarhus C, Denmark \\ ${ }^{b}$ Department of Environmental Science, College of Environment and Natural Resources, Can Tho University, 3/2 Street, Can Tho City, Vietnam
}

\section{A R T I C L E I N F O}

Article history:

Received 10 June 2010

Received in revised form 16 December 2010

Accepted 16 December 2010

Available online 7 January 2011

\section{Keywords:}

Aquaculture wastewater

Canna

Common carp

Nile tilapia

Ornamental plants

Tropical

\begin{abstract}
A B S T R A C T
Common practice of aquaculture in Vietnam and other countries in South East Asia involves frequent discharge of polluted water into rivers which results in eutrophication and degradation of receiving water bodies. There is therefore a need to develop improved aquaculture systems which have a more efficient use of water and less environmental impact. The aim of this study was to assess the suitability of using constructed wetlands (CWs) for the treatment of fishpond water in a recirculating aquaculture system in the Mekong Delta of Vietnam. Water from a fishpond stocked with Nile tilapia (Oreochromis niloticus) and common carp (Cyprinus carpio) was recirculated through horizontal and vertical flow CWs. The CWs were able to keep a good water quality with DO $\left(>1 \mathrm{mg} / \mathrm{l}^{-1}\right)$, BOD $\left(<30 \mathrm{mg} \mathrm{l}^{-1}\right)$, TAN $\left(<1 \mathrm{mg} \mathrm{l}^{-1}\right)$ and $\mathrm{NO}_{2}^{-}\left(<0.07 \mathrm{mg} \mathrm{l}^{-1}\right)$ at acceptable concentrations for growth of the fish. There was a good removal of organic matter measured as oxygen demand with up to 50\% removal of BOD and COD in both types of CWs despite the high loading rates and low concentration levels. However, the vertical flow CWs performed better than the horizontal flow CWs as they had higher nitrification rates and higher DO concentrations in the outlets. The ornamental Canna $\times$ generalis planted in the CWs grew faster and took up more $\mathrm{N}$ and $\mathrm{P}$ in the vertical flow CWs. The aquaculture fish had a feed conversion ratio of 1.53 based on feed dry weight, and $31 \%$ and $34 \%$ of $\mathrm{N}$ and $\mathrm{P}$ input, respectively, were incorporated into fish biomass. Only minor quantities of phytoplankton algae were removed in the CWs but abundance of toxic algae such as Microcystis was low. It is concluded that particularly vertical flow CWs have great potential for treatment of fishpond water in recirculating aquaculture systems in the tropics as the discharge of polluted water and the associated environmental impact can be significantly reduced.
\end{abstract}

(c) 2011 Elsevier B.V. All rights reserved.

\section{Introduction}

The Mekong Delta in southern Vietnam has an area of around $40,000 \mathrm{~km}^{2}$ and is a very productive region for brackish and freshwater aquaculture. In the early 1990 s, less than $5 \%$ of the total area suitable for aquaculture was devoted to it, while large areas were used for rice fields and fruit orchards, but in $200422 \%$ of the agricultural land was used for aquaculture (Nhan et al., 2007). In 2007, the total aquaculture production in the Mekong Delta was 2.2 million tons of which catfish constituted around 30\%. In aquaculture, water management plays an important role as the farmers have to keep the conditions in the fishponds adequate for the growth of fish. Hence, polluted water from the ponds is frequently exchanged with water from the rivers at intervals typically ranging from daily to once a week. The frequency of exchange is gradually increased towards the time of harvesting and may

\footnotetext{
* Corresponding author. Tel.: + 45 89424701; fax: + 4589424747.

E-mail address: dennis.konnerup@biology.au.dk (D. Konnerup).
}

in catfish ponds be as high as twice a day and the replenishment volume may range between 30 and $100 \%$. It has been estimated that $47.3 \mathrm{~kg}$ nitrogen $(\mathrm{N})$ is discharged per ton catfish produced, and on this basis the production of catfish alone resulted in the discharge of 32,300 tons of $\mathrm{N}$ in the Mekong Delta in 2007 (Phan et al., 2009). Another aquaculture system that is widely used in the Mekong Delta is an integrated agriculture and aquaculture system, where the farmers dispose livestock manure into fishponds to feed the fish. This system has been developed to use on-farm resources in pond culture to produce fish and at the same time reduce environmental impacts of the farming activity. However, the farmers often do not control the load of manure to the fishpond in accordance with the needs of the fish, but use the fishponds for waste disposal and the water still has to be exchanged with river water to keep a good water quality for the fish (Nhan et al., 2008).

The discharge of polluted water from aquaculture systems causes eutrophication and other deleterious effects in the receiving water bodies. Furthermore, the common practice with frequent exchange of river water results in the spread of diseases between fish farms. Farmers consequently use large quantities of prophylactic antibiotics. This can result in the accumulation of antibiotic residues in water and 
sludge which leads to antibiotic resistance among fish pathogens (Le and Munekage, 2004; Cabello, 2006). There is therefore a need to develop more sustainable aquaculture production systems both in terms of environmental impact as well as fish production. A possible solution could be to recycle the fishpond water after adequate treatment in constructed wetlands (CWs) and thereby achieve close to zero-discharge systems (Tilley et al., 2002). Advantages of CWs are the utilisation of natural processes, the high process stability and their cost-effectiveness. Furthermore, CWs are relatively simple to construct and operate which is a prerequisite in many developing countries. In Vietnam, CWs have been reported to be very suitable for the treatment of several types of wastewater (Trang et al., 2010; Dan et al., in press).

Subsurface flow CWs basically consist of a bed of sand or gravel, wherein emergent wetland plants are planted. Water flows either horizontally or vertically through the bed medium where the pollutants are decomposed as a result of mainly microbial activity. The plants have several roles in the CWs, including uptake of nutrients which can subsequently be removed through harvest of the aboveground biomass (Brix, 1997). Traditionally, fast-growing wetland species like Phragmites spp. and Typha spp. are used in the CWs. However, recently, and particularly in the tropics, great emphasis has been put on increasing the aesthetics of the systems by using ornamental flowers like Canna spp. and other species (Brix et al., 2007; Konnerup et al., 2009; Zurita et al., 2009).

The aim of the present study was to assess the suitability of using CWs as a tool to treat fishpond water in recirculating aquaculture systems, and to compare the performance of CWs with vertical and horizontal subsurface flow. Water from a traditional fishpond was treated in duplicate pilot-scale CWs with either horizontal or vertical subsurface flow and recirculated back to the fishpond. During the 4.5 month experimental period, no water was discharged from the system to the environment. Water quality as well as fish growth were monitored, and the performances of the two types of CWs were compared in relation to hydraulic loading rate.

\section{Materials and methods}

\subsection{Experimental setup}

The study was carried out at Can Tho University in Vietnam $\left(10^{\circ} 01^{\prime} \mathrm{N}, 105^{\circ} 45^{\prime} \mathrm{E}\right)$. The fishpond used in the experiment had a size of $8 \mathrm{~m} \times 8 \mathrm{~m}$ with a maximum depth of $1 \mathrm{~m}$ and a volume of around $40 \mathrm{~m}^{3}$. The pond was lined by a plastic membrane to avoid exchange with ground water. The fish population in the pond was a polyculture of Nile tilapia (Oreochromis niloticus - $85 \%$ of fish biomass) and common carp (Cyprinus carpio - 15\% of fish biomass). The pond was stocked with a total of $14.9 \mathrm{~kg}$ fish, and after 4.5 months $125 \mathrm{~kg}$ fish was harvested. Only $1.8 \mathrm{~kg}$ of fish died during the study.

At the bank of the fishpond two horizontal flow CWs (HFCWs) and two vertical flow CWs (VFCWs) were set up (Fig. 1). The HFCWs (width $0.85 \mathrm{~m}$; length $3.7 \mathrm{~m}$ ) were built of wood and metal plates and lined by a double layer of a plastic liner (Fig. 2). The HFCWs were filled with coarse gravel ( $\varnothing 30-50 \mathrm{~mm}$ ) to a depth of $0.3 \mathrm{~m}$. The VFCWs were set up in 1.25 m diameter plastic containers. In the bottom of the containers a system of perforated $\emptyset 90 \mathrm{~mm}$ PVC pipes was placed to secure efficient drainage of the VFCWs. The total depth of the VFCW filters were $0.7 \mathrm{~m}$ and the media consisted of (from bottom to top) a $0.1 \mathrm{~m}$ layer of stones ( $\varnothing 50-100 \mathrm{~mm}$ ), a $0.4 \mathrm{~m}$ layer of coarse gravel (Ø 30-50 mm) and on top a 0.2 m layer of fine gravel (Ø 10-20 mm). On the surface of the filters, a system of perforated $\varnothing 21 \mathrm{~mm}$ pipes was installed to facilitate an even distribution of the influent over the surface of the VFCWs. All four CW units were planted with a mixture of different Canna $\times$ generalis cultivars with a height of approximately $0.5 \mathrm{~m}$ at planting. After construction and planting, the systems were allowed to acclimatize for 3 months in order to let the plants and the

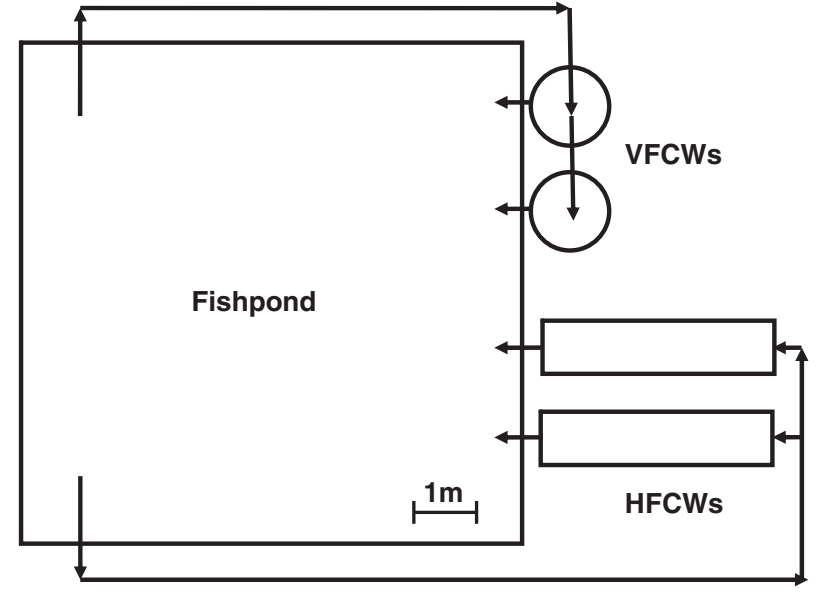

Fig. 1. Schematic overview of the fishpond with vertical flow constructed wetlands (VFCWs) and horizontal flow constructed wetlands (HFCWs). Arrows show the circulation of water from the pond, through the VFCWs and HFCWs and back to the pond.

microorganisms develop. During this period the CWs were loaded with water from the fishpond at loading rates varying between 1000 and $3000 \mathrm{~mm} \mathrm{~d}^{-1}$.

\subsection{Water loading}

Water from the fishpond was loaded to the CWs with pumps. The HFCWs were loaded continuously and the loading rate controlled by valves. The VFCWs were pulse-loaded using timer-controlled pumps (30 s of loading followed by a resting period of 2-10 min depending on the loading rate). Three hydraulic loading rates (HLRs) were tested in the CWs; $750 \mathrm{~mm} \mathrm{~d}^{-1}, 1500 \mathrm{~mm} \mathrm{~d}^{-1}$ and $3000 \mathrm{~mm} \mathrm{~d}^{-1}$. The trial with the HLR of $750 \mathrm{~mm} \mathrm{~d}^{-1}$ was conducted first and between each trial the wetland units were allowed to acclimatize to the new HLR for approximately 2 weeks before the treatment performance was monitored. Water samples from the inlets to the horizontal and vertical systems and from each of the outlets from the systems were taken daily between 7 and 8 o'clock in the morning for 4 consecutive days at the end of each trial. Evapotranspiration from the system was determined by measuring the water level in the fishpond daily.

\subsection{Water analysis}

Temperature, electric conductivity (EC), pH and dissolved oxygen (DO) were measured immediately after sampling by a conductivity meter (Thermo Orion model 105), a portable pH meter (HANNA HI 8424) and a DO meter (HANNA HI 9146). Biological oxygen demand $\left(\mathrm{BOD}_{5}\right)$, chemical oxygen demand (COD), total Kjeldahl nitrogen (TKN), nitrite $\left(\mathrm{NO}_{2}^{-}-\mathrm{N}\right)$, total phosphorus (TP) and ortho-phosphate $\left(\mathrm{PO}_{4}^{3-}-\mathrm{P}\right)$ were analysed following standard procedures (APHA, 1998). Total ammonia nitrogen (TAN) was analysed using a modified salicylate method (Quikchem Method no. 10-107-06-3-B, Lachat Instruments, Milwaukee, WI, USA). Nitrate $\left(\mathrm{NO}_{3}^{-}-\mathrm{N}\right)$ was analysed after reduction to nitrite $\left(\mathrm{NO}_{2}^{-}\right)$in commercial cadmium columns (Foss Analytical AB, Höganäs, Sweden) and subsequently analysed as $\mathrm{NO}_{2}^{-}$. TN was calculated as the sum of TKN, $\mathrm{NO}_{2}^{-}$and $\mathrm{NO}_{3}^{-}$.

\subsection{Plant analysis}

Correlations of plant height and weight were prepared for each CW unit by harvesting at least 60 shoots from each CW and measuring height and weight. Hereafter, corresponding heights and weights were fitted with power functions (Spencer et al., 2006). Subsequently, the obtained power functions $\left(R^{2}=0.74-0.84\right)$ were used to estimate 

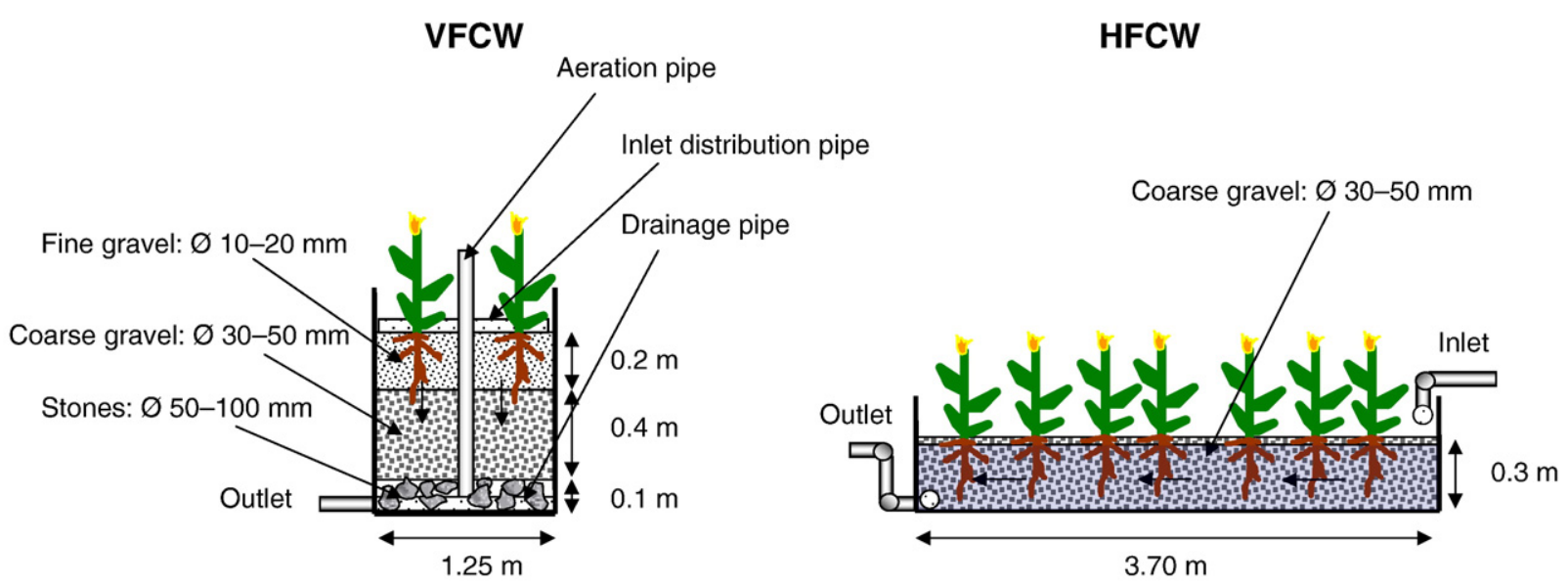

Fig. 2. Schematic diagram of a vertical flow constructed wetland (VFCW) and a horizontal flow constructed wetland (HFCW).

standing biomass in the CWs at the beginning and end of a 51-day period to determine the shoot growth rates. Relative growth rates (RGR) were calculated as the difference in the natural logarithm of final and initial weights divided by the growth period in days. At the end of the study period, 5-6 shoots from each CW were harvested and dried at $70{ }^{\circ} \mathrm{C}$ until constant weight. The shoots were ground and analysed for concentrations of total $\mathrm{N}$ and carbon (C) by gas chromatography after combustion of 2 to $3 \mathrm{mg}$ dried plant material (Fisons Instruments, Model NA2000, Carlo Erba, Italy).

The concentrations of calcium (Ca), potassium (K), magnesium $(\mathrm{Mg})$ and phosphorous $(\mathrm{P})$ in the plant tissues were analysed in subsamples (150-180 mg) of finely ground dried plant material. The samples were digested in a microwave sample preparation system (Multiwave 3000, Anton Paar GmbH, Austria) using 4 ml concentrated $\mathrm{HNO}_{3}$ and $2 \mathrm{ml} \mathrm{H}_{2} \mathrm{O}_{2}$. The concentrations of the elements were analysed by inductively coupled plasma spectrometry (Optima 2000 DV, Perkin Elmer Instruments Inc., CT, USA).

\subsection{Fish growth, feeding and feed composition}

The fish were fed twice daily with a commercial feed (Aquafeed GB625) which contained $25 \%$ crude protein, $4 \%$ crude fat, $10 \%$ crude ash, $8 \%$ crude fiber, $4 \%$ nitrogen, $1 \%$ phosphorus and $11 \%$ moisture. Feeding rates were set at $3 \%$ of the estimated body weight of the fish and adjusted according to the intake rates of the fish. Total feed addition in the experimental period was $190 \mathrm{~kg}$. At the end of the study period, fish biomass was determined by weighing all the fish. Three to five specimens of each species were dried at $70{ }^{\circ} \mathrm{C}$ until constant weight, ground and analysed for $\mathrm{C}, \mathrm{N}$ and $\mathrm{P}$ following the same analytical procedures as for the plant samples. Feed conversion ratio (FCR) and nutrient conversion rates of $\mathrm{N}$ and $\mathrm{P}$ were calculated according to the equations:

$\mathrm{FCR}=$ total feed dry weight/(final fish biomass -initial fish biomass)

nutrient conversion rates $=(A-B) \times 100 / C$

where $\mathrm{A}$ is the total nutrient in fish biomass at harvest, $\mathrm{B}$ is the total nutrient in fish biomass at start and $C$ is the total nutrient in feed given.

\subsection{Phytoplankton}

At each trial, samples from all inlets, outlets and the fishpond were sampled to determine the taxonomic composition and abundance of different phytoplankton groups in the system. For phytoplankton enumeration, a Sedgwick-Rafter counting cell was used as described in APHA (1998). Phytoplankton cell counting of the preserved cells was undertaken at $125 \times$ magnification using a $1 \mathrm{ml}$ volume SedgwickRafter counting chamber. A correction factor was applied to allow for the dilution caused by the added preservative. Dilution or concentration techniques were applied to samples when appropriate to facilitate counting.

\subsection{Data analysis}

Data were analysed by analysis of variance (ANOVA) using Type III sum of squares with the software Statgraphics XV centurion version 15.1.02 (StatPoint, Inc., USA). The replicate CW units were entered into the model as a block effect, but since the block effect was not significant for any of the tested parameters, data from the replicate units were pooled in the ANOVA. Posthoc multiple comparisons of means were performed using Tukey HSD procedure at the 0.05 significance level. All data were tested for normal distribution by Kolmogorov-Smirnov tests and for homogeneity of variance by Bartlett's tests. If necessary, logarithmic or square root transformations were performed to ensure homogeneity of variance, but for clarity all data are presented as untransformed.

\section{Results}

\subsection{Plant growth and evapotranspiration}

The Canna $\times$ generalis grew well in both HFCWs and VFCWs (Table 1), but the plants in the VFCWs had a substantially higher growth rate and final shoot height compared to plants in the HFCWs $(P<0.01)$. Extrapolating from the Canna $\times$ generalis biomass produced during the study period, the estimated yearly aboveground biomass production was 8.2 and $15.5 \mathrm{~kg} \mathrm{DW} \mathrm{m}^{-2}$ year $^{-1}$, for HFCWs and VFCWs, respectively.

Table 1

Shoot height and estimated growth rates of above-ground biomass, $\mathrm{N}$ and $\mathrm{P}$ concentrations and uptake rates in Canna $\times$ generalis grown in horizontal flow (HF) or vertical flow (VF) constructed wetlands treating fish pond water.

\begin{tabular}{lll}
\hline & HF & VF \\
\hline Shoot height $(\mathrm{cm} \pm \mathrm{SD})$ & $134 \pm 27$ & $155 \pm 38$ \\
Shoot growth rate $\left(\mathrm{g} \mathrm{DW} \mathrm{m} \mathrm{m}^{-2} \mathrm{~d}^{-1}\right)$ & 22.6 & 42.6 \\
$\mathrm{RGR}\left(\mathrm{g} \mathrm{g}^{-1} \mathrm{~d}^{-1}\right)$ & 0.030 & 0.054 \\
$\mathrm{~N}$ conc. $(\% \mathrm{DW})$ & 1.66 & 2.28 \\
$\mathrm{~N}$ uptake rate $\left(\mathrm{g} \mathrm{m}^{-2} \mathrm{~d}^{-1}\right)$ & 0.38 & 0.97 \\
$\mathrm{P}$ conc. $\% \mathrm{DW})$ & 0.43 & 0.51 \\
$\mathrm{P}$ uptake rate $\left(\mathrm{g} \mathrm{m}^{-2} \mathrm{~d}^{-1}\right)$ & 0.098 & 0.215 \\
\hline
\end{tabular}


Table 2

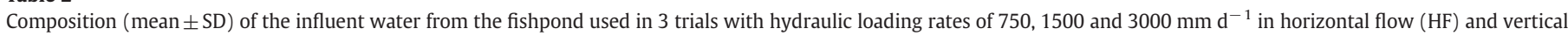
flow (VF) constructed wetlands and results of one-way ANOVA statistics (F-ratios).

\begin{tabular}{|c|c|c|c|c|c|c|c|}
\hline & \multicolumn{2}{|l|}{$750 \mathrm{~mm} \mathrm{~d}^{-1}$} & \multicolumn{2}{|l|}{$1500 \mathrm{~mm} \mathrm{~d}^{-1}$} & \multicolumn{2}{|l|}{$3000 \mathrm{~mm} \mathrm{~d}^{-1}$} & \multirow[b]{2}{*}{ F-ratio } \\
\hline & $\mathrm{HF}$ & VF & $\mathrm{HF}$ & VF & $\mathrm{HF}$ & VF & \\
\hline Temp. $\left({ }^{\circ} \mathrm{C}\right)$ & $30.1 \pm 0.2^{b}$ & $29.8 \pm 0.2^{b}$ & $29.2 \pm 0.8^{\mathrm{ab}}$ & $29.3 \pm 0.8^{\mathrm{ab}}$ & $27.9 \pm 1.6^{\mathrm{a}}$ & $27.9 \pm 1.6^{\mathrm{a}}$ & $3.4^{*}$ \\
\hline $\mathrm{pH}$ & $7.2 \pm 0.1$ & $7.4 \pm 0.2$ & $7.5 \pm 0.2$ & $7.5 \pm 0.2$ & $7.3 \pm 0.1$ & $7.4 \pm 0.1$ & $1.6^{\mathrm{NS}}$ \\
\hline Conductivity $\left(\mu \mathrm{S} \mathrm{cm}^{-1}\right)$. & $419 \pm 7^{b}$ & $416 \pm 7^{b}$ & $413 \pm 26^{\mathrm{b}}$ & $413 \pm 26^{b}$ & $358 \pm 25^{a}$ & $359 \pm 26^{a}$ & $7.4^{* * *}$ \\
\hline $\mathrm{DO}\left(\mathrm{mg} \mathrm{l}^{-1}\right)$ & $6.32 \pm 0.73$ & $6.37 \pm 1.50$ & $6.29 \pm 0.99$ & $5.33 \pm 1.37$ & $5.35 \pm 1.42$ & $5.22 \pm 1.75$ & $0.7^{\mathrm{NS}}$ \\
\hline $\mathrm{BOD}\left(\mathrm{mg} \mathrm{l}^{-1}\right)$ & $16 \pm 5$ & $15 \pm 4$ & $25 \pm 5$ & $27 \pm 7$ & $23 \pm 15$ & $26 \pm 19$ & $0.9^{\mathrm{NS}}$ \\
\hline $\operatorname{COD}\left(\mathrm{mg} \mathrm{l}^{-1}\right)$ & $127 \pm 12$ & $121 \pm 10$ & $113 \pm 12$ & $127 \pm 40$ & $126 \pm 17$ & $162 \pm 27$ & $2.5^{\mathrm{NS}}$ \\
\hline $\mathrm{TN}\left(\mathrm{mg} \mathrm{l}^{-1}\right)$ & $6.55 \pm 1.15^{\mathrm{a}}$ & $6.19 \pm 0.95^{\mathrm{a}}$ & $6.98 \pm 0.05^{\mathrm{a}}$ & $8.19 \pm 1.11^{\mathrm{ab}}$ & $7.96 \pm 0.51^{\mathrm{ab}}$ & $9.66 \pm 0.57^{b}$ & $9.4^{\text {*** }}$ \\
\hline TAN $\left(\mathrm{mg} \mathrm{l}^{-1}\right)$ & $0.39 \pm 0.21$ & $0.31 \pm 0.17$ & $0.66 \pm 0.16$ & $0.85 \pm 0.14$ & $0.51 \pm 0.33$ & $0.60 \pm 0.34$ & $2.7^{\mathrm{NS}}$ \\
\hline $\mathrm{NO}_{2}^{-}-\mathrm{N}\left(\mathrm{mg} \mathrm{l}^{-1}\right)$ & $0.011 \pm 0.001^{\mathrm{a}}$ & $0.011 \pm 0.001^{\mathrm{a}}$ & $0.006 \pm 0.001^{\mathrm{a}}$ & $0.006 \pm 0.001^{\mathrm{a}}$ & $0.070 \pm 0.036^{\mathrm{b}}$ & $0.057 \pm 0.028^{\mathrm{b}}$ & $9.7^{* * *}$ \\
\hline $\mathrm{NO}_{3}^{-}-\mathrm{N}\left(\mathrm{mg} \mathrm{l}^{-1}\right)$ & $0.02 \pm 0.01^{\mathrm{a}}$ & $0.02 \pm 0.01^{\mathrm{a}}$ & $0.01 \pm 0.01^{\mathrm{a}}$ & $0.02 \pm 0.02^{\mathrm{a}}$ & $0.06 \pm 0.02^{\mathrm{b}}$ & $0.06 \pm 0.00^{\mathrm{b}}$ & $15.0^{* * *}$ \\
\hline $\mathrm{TP}\left(\mathrm{mg} \mathrm{l}^{-1}\right)$ & $1.04 \pm 0.03^{\mathrm{a}}$ & $1.00 \pm 0.08^{\mathrm{a}}$ & $1.51 \pm 0.17^{\mathrm{b}}$ & $1.61 \pm 0.30^{\mathrm{b}}$ & $2.30 \pm 0.25^{c}$ & $2.49 \pm 0.22^{c}$ & $42.8^{* * *}$ \\
\hline $\mathrm{PO}_{4}^{3-}-\mathrm{P}\left(\mathrm{mg} \mathrm{l}^{-1}\right)$ & $0.28 \pm 0.04^{\mathrm{a}}$ & $0.27 \pm 0.08^{\mathrm{a}}$ & $0.92 \pm 0.04^{\mathrm{b}}$ & $0.91 \pm 0.03^{b}$ & $1.30 \pm 0.15^{\mathrm{c}}$ & $1.40 \pm 0.14^{\mathrm{c}}$ & $104.1^{\text {*** }}$ \\
\hline
\end{tabular}

Different letter superscripts between columns indicate significant difference.

NS: not significant.

* $P<0.05$.

*** $P<0.001$.

Net evapotranspiration, which is the sum of the physical evaporation from the fishpond and CW surfaces and the transpiration by the plants, was measured to be ca. $440 \mathrm{l} \mathrm{d}^{-1}$ during the study period. This corresponds to an average net evapotranspiration rate for the total fishpond and CW area of $6 \mathrm{~mm} \mathrm{~d}^{-1}$.

\subsection{Water quality}

The inlet water to the two types of CWs was pumped from two different locations in the fishpond (Fig. 1) and none of the measured water quality parameters differed significantly between these inlets (Table 2). Inlet water pH, DO, BOD, COD, and TAN did not differ between the 3 trials, but $\mathrm{N}$ and $\mathrm{P}$ concentrations increased significantly over time and were highest in the last trial (at a HLR of $3000 \mathrm{~mm} \mathrm{~d}^{-1}$ ). The temperature in the fishpond was in the range $26.6-30.4{ }^{\circ} \mathrm{C}$ during the study.

Outlet pH and EC were significantly affected by both CW type and HLR, but there were no significant interactions between the factors in the two-way ANOVA (Table 3). Generally, pH was higher in the outlets from the VFCWs and more so at low loadings (Fig. 3). The DO concentrations in the outlets were significantly affected by both $\mathrm{CW}$ type and HLR, and there was a significant interaction between CW type and HLR showing that the effect of HLR differed between CW type (Table 3). Outlet DO concentrations from the VFCWs were in the range 5.3-6.1 $\mathrm{mg} \mathrm{l}^{-1}$ and were significantly higher than the DO in outlets from the HFCWs, especially at the low HLR of $750 \mathrm{~mm} \mathrm{~d}^{-1}$ where the mean outlet DO concentration of the HFCWs was $2.3 \mathrm{mg} \mathrm{l}^{-1}$. Moreover, the outlet DO concentrations from the HFCWs were substantially lower than the inlet concentrations at the low HLRs (Fig. 3). Outlet concentrations of BOD and COD did not differ significantly between the two CW types but were significantly higher at the highest HLR of $3000 \mathrm{~mm} \mathrm{~d}^{-1}$ (Table 3 and Fig. 3). In general, there was a good removal of BOD and COD of up to $50 \%$ in both CW types although HLRs were very high (Fig. 3).

Outlet concentrations of TN were in the range 4.5-8.2 $\mathrm{mg} \mathrm{l}^{-1}$ and were not affected by CW type, but concentrations increased with HLR, i.e. over time (Table 3 and Fig. 4). In contrast, outlet concentrations of TAN were not affected by HLR but by CW type with lower concentrations in the VFCWs (Table 3 and Fig. 4). $\mathrm{NO}_{2}^{-}$outlet concentrations were generally low $\left(<0.07 \mathrm{mg} \mathrm{l}^{-1}\right)$ but were affected by both CW type and HLR. Inlet concentrations of $\mathrm{NO}_{3}^{-}$were low $\left(0.01-0.07 \mathrm{mg} \mathrm{l}^{-1}\right)$ but outlet concentrations were significantly higher, particularly in the VFCWs because of a substantial nitrification activity in the VFCWs. The majority of $\mathrm{N}$ was in the form of organic $\mathrm{N}$ in inlets and outlet of both $\mathrm{CW}$ types.
Outlet TP concentrations did not differ between CW types but increased over time with higher concentrations at high HLR (Table 3 and Fig. 4). HLR also affected outlet concentrations of $\mathrm{PO}_{4}^{3-}$ which were also higher in the outlet from the VFCWs. There was no substantial removal of $\mathrm{P}$ in the CWs and the concentrations increased during the study period due to the accumulation of organic $\mathrm{P}$ and $\mathrm{PO}_{4}^{3-}$ in the water.

\subsection{Plant nutrient concentrations and uptake}

The plants in the VFCWs had significantly higher concentrations of $\mathrm{N}$ in the aboveground biomass and significantly lower $\mathrm{C}$ concentrations and $\mathrm{C} / \mathrm{N}$ ratios compared to plants grown in the HFCWs (Table 4). The plants in the VFCWs had higher growth rates and higher $\mathrm{N}$ concentrations in shoots compared to plants in HFCWs, and this resulted in a much higher $\mathrm{N}$ uptake rate for plants in VFCWs $\left(0.97 \mathrm{~g} \mathrm{~m}^{-2} \mathrm{~d}^{-1}\right)$ than for plants in HFCWs $\left(0.38 \mathrm{~g} \mathrm{~m}^{-2} \mathrm{~d}^{-1}\right.$ ) (Table 1$)$. Plants in the VFCWs also had significantly higher concentrations of $\mathrm{K}$ in the shoots whereas concentrations of Ca, Mg and P did not differ between CW type (Table 4). For $\mathrm{P}$, the uptake rates in aboveground biomass were $0.098 \mathrm{~g} \mathrm{~m}^{-2} \mathrm{~d}^{-1}$ and $0.215 \mathrm{~g} \mathrm{~m}^{-2} \mathrm{~d}^{-1}$, for HFCWs and VFCWs, respectively. For practical reasons we did not estimate the belowground biomass production and

Table 3

Results of two-way ANOVA (F-ratios) showing the effects of constructed wetland design (horizontal flow (HF) and vertical flow (VF)) and 3 hydraulic loading rates (HLR: 750,1500 or $3000 \mathrm{~mm} \mathrm{~d}^{-1}$ ) on effluent water quality of the systems treating fish pond water.

\begin{tabular}{|c|c|c|c|}
\hline & \multicolumn{2}{|c|}{ Main effects } & \multirow{2}{*}{$\frac{\text { Interaction }}{\text { CW type } \times \text { HLR }}$} \\
\hline & CW type & HLR & \\
\hline Temp. $\left({ }^{\circ} \mathrm{C}\right)$ & $0.01^{\mathrm{NS}}$ & $22.47^{* * *}$ & $0.14^{\mathrm{NS}}$ \\
\hline $\mathrm{pH}$ & $6.04^{*}$ & $4.00^{*}$ & $2.89^{\mathrm{NS}}$ \\
\hline Conductivity $\left(\mu \mathrm{S} \mathrm{cm}{ }^{-1}\right)$ & $8.69^{* *}$ & $32.27^{* * *}$ & $0.17^{\mathrm{NS}}$ \\
\hline $\mathrm{DO}\left(\mathrm{mg} \mathrm{l}^{-1}\right)$ & $87.52^{* * *}$ & $3.35^{*}$ & $11.72^{* * *}$ \\
\hline $\mathrm{BOD}\left(\mathrm{mg} \mathrm{l}^{-1}\right)$ & $1.62^{\mathrm{NS}}$ & $4.57^{*}$ & $0.66^{\mathrm{NS}}$ \\
\hline $\mathrm{COD}\left(\mathrm{mg} \mathrm{l}^{-1}\right)$ & $0.06^{\mathrm{NS}}$ & $20.51^{* * *}$ & $2.32^{\mathrm{NS}}$ \\
\hline $\mathrm{TN}\left(\mathrm{mg} \mathrm{l}^{-1}\right)$ & $0.29^{\mathrm{NS}}$ & $34.66^{* * *}$ & $0.03^{\mathrm{NS}}$ \\
\hline $\operatorname{TAN}\left(\mathrm{mg} \mathrm{l}^{-1}\right)$ & $99.28^{* * *}$ & $3.15^{\mathrm{NS}}$ & $12.91^{* * *}$ \\
\hline $\mathrm{NO}_{2}^{-}-\mathrm{N}\left(\mathrm{mg} \mathrm{l}^{-1}\right)$ & $11.38^{* *}$ & $16.44^{* * *}$ & $1.61^{\mathrm{NS}}$ \\
\hline $\mathrm{NO}_{3}^{-}-\mathrm{N}\left(\mathrm{mg} \mathrm{l}^{-1}\right)$ & $222.26^{* * *}$ & $104.99^{* * *}$ & $117.83^{* * *}$ \\
\hline $\mathrm{TP}\left(\mathrm{mg} \mathrm{l}^{-1}\right)$ & $0.18^{\mathrm{NS}}$ & $140.23^{* * *}$ & $3.57^{*}$ \\
\hline $\mathrm{PO}_{4}^{3-}-\mathrm{P}\left(\mathrm{mg} \mathrm{l}^{-1}\right)$ & $12.00^{* *}$ & $567.80^{* * *}$ & $15.42^{* * *}$ \\
\hline
\end{tabular}

${ }^{*} P<0.05 ;{ }^{* *} P<0.01 ;{ }^{* * *} P<0.001$; NS: not significant. 

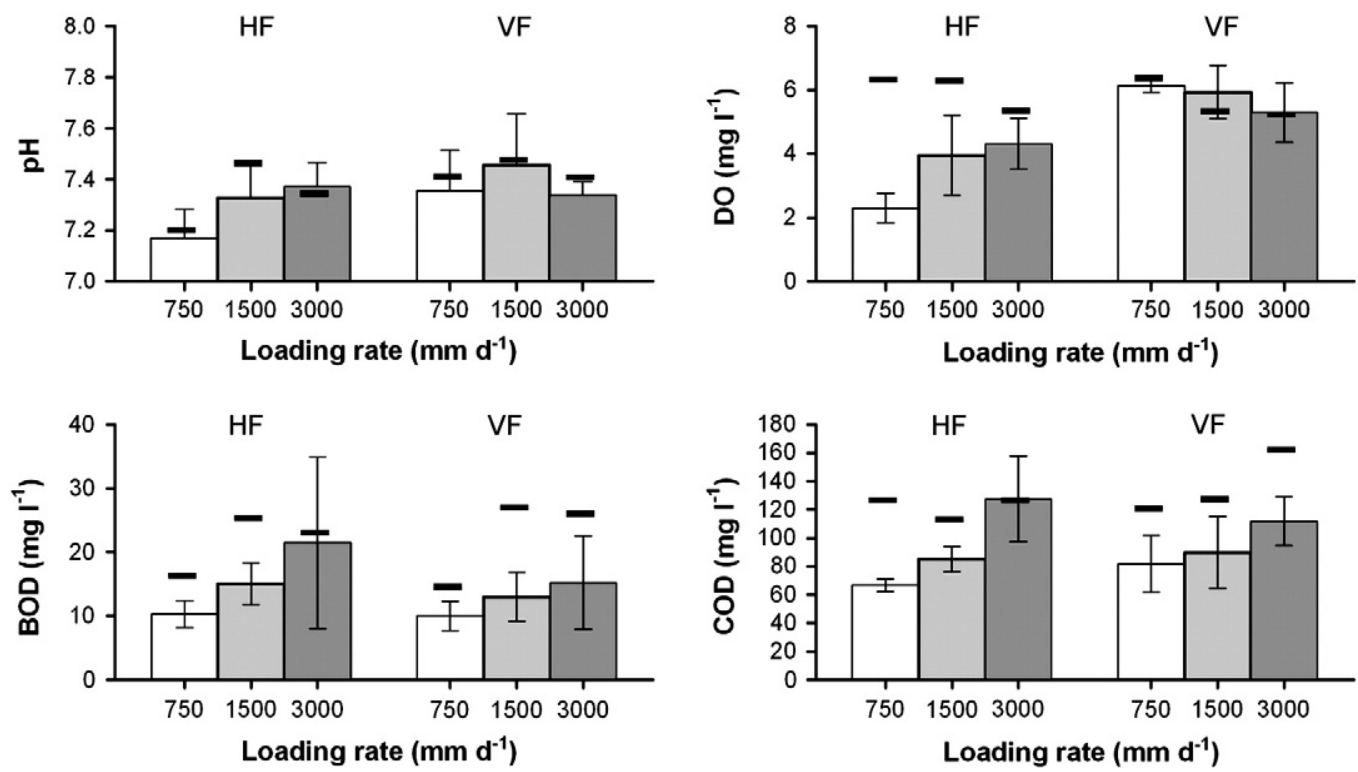

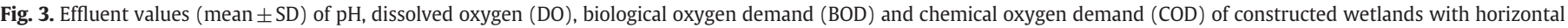
flow (HF) or vertical flow (VF) treating water from a fishpond. Horizontal bars above the columns show the mean inlet concentrations from Table 1.

associated nutrient uptake. As the belowground biomass cannot be harvested, incorporation of nutrients into belowground biomass is not a sustainable removal pathway in the long term, as old roots and rhizomes will after death and decay, release the bound nutrients back into the water.
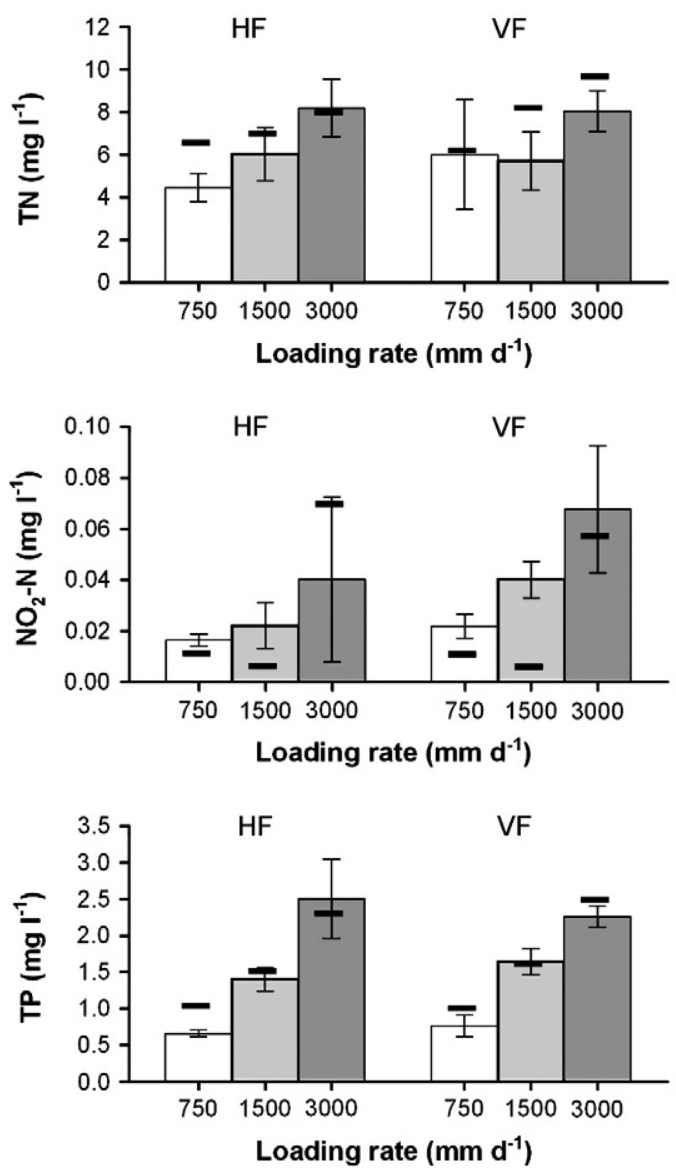

\subsection{Fish feeding and growth}

The fish in the fishpond were a polyculture of Nile tilapia (Oreochromis niloticus) and common carp (Cyprinus carpio) of which Nile tilapia constituted the main part ( $85 \%$ of biomass). First, a total of
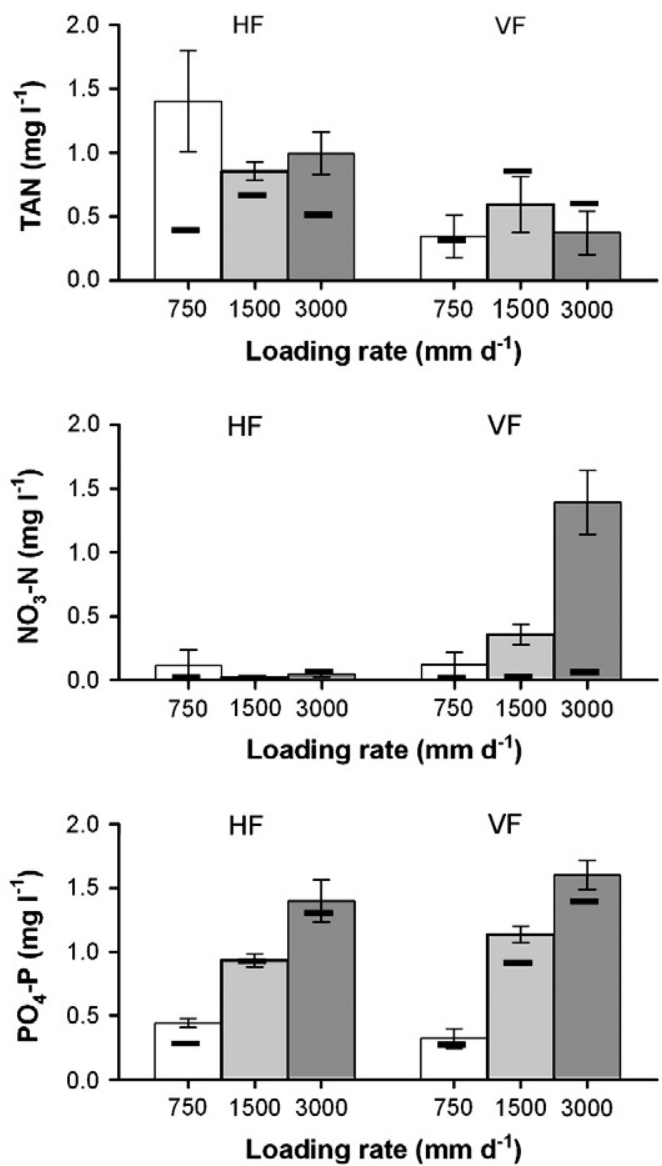

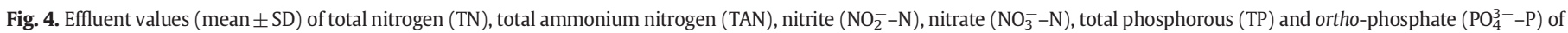

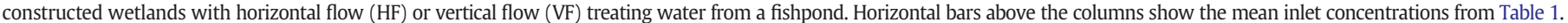


Table 4

Concentrations of total $\mathrm{N}$, total $\mathrm{C}, \mathrm{C} / \mathrm{N}$-ratio and concentrations of $\mathrm{Ca}, \mathrm{K}, \mathrm{Mg}$, and $\mathrm{P}$ (mean $\pm \mathrm{SD}$ ) in shoots of Canna $\times$ generalis grown in horizontal flow (HF) or vertical flow (VF) constructed wetlands treating fish pond water and results of one-way ANOVA (F-ratios).

\begin{tabular}{|c|c|c|c|}
\hline & $\mathrm{HF}$ & VF & F-ratio \\
\hline Total N ( $\left.\mathrm{mg} \mathrm{g}^{-1} \mathrm{DW}\right)$ & $16.6 \pm 2.9$ & $22.8 \pm 4.0$ & $17.51^{* * *}$ \\
\hline Total C ( $\left.\mathrm{mg} \mathrm{g}^{-1} \mathrm{DW}\right)$ & $416 \pm 21$ & $385 \pm 21$ & $12.17^{* *}$ \\
\hline $\mathrm{C} / \mathrm{N}$-ratio (by atom) & $30.2 \pm 6.4$ & $20.5 \pm 5.2$ & $14.30^{* *}$ \\
\hline $\mathrm{C} / \mathrm{N}$-ratio (by weight) & $25.9 \pm 5.5$ & $17.6 \pm 4.5$ & $14.30^{* *}$ \\
\hline $\mathrm{Ca}\left(\mathrm{mg} \mathrm{g}^{-1} \mathrm{DW}\right)$ & $7.0 \pm 1.1$ & $6.4 \pm 1.1$ & $1.48^{\mathrm{NS}}$ \\
\hline $\mathrm{K}\left(\mathrm{mg} \mathrm{g}^{-1} \mathrm{DW}\right)$ & $50 \pm 19$ & $76 \pm 10$ & $13.00^{* *}$ \\
\hline $\operatorname{Mg}\left(\mathrm{mg} \mathrm{g}^{-1} \mathrm{DW}\right)$ & $3.4 \pm 0.6$ & $3.8 \pm 0.8$ & $2.05^{\mathrm{NS}}$ \\
\hline $\mathrm{P}\left(\mathrm{mg} \mathrm{g}^{-1} \mathrm{DW}\right)$ & $4.3 \pm 1.1$ & $5.1 \pm 0.9$ & $3.32^{\mathrm{NS}}$ \\
\hline
\end{tabular}

NS: not significant.

*** $P<0.001$.

** $P<0.01$.

$11 \mathrm{~kg}$ Nile tilapia was added to the pond. After 6 weeks, $3.7 \mathrm{~kg}$ common carp was added to the pond. 19 weeks after the initial stocking of the pond, all fish were caught and weighed to determine the weight increments. The final weight of tilapia was $113 \mathrm{~kg}$ and the weight of common carp was $12 \mathrm{~kg}$. The FCRs were 1.71 based on feed fresh weight and 1.53 based on feed dry weight.

Calculations of nutrient conversion ratios showed that $\mathrm{N}$ and $\mathrm{P}$ incorporated into the fish biomass accounted for $31 \%$ and $34 \%$ of the $\mathrm{N}$ and $\mathrm{P}$ input with the feed, respectively.

\subsection{Phytoplankton}

Phytoplankton from 3 different phyla and 30 genera were identified in the fishpond and CW system during the study period (Table 5). Based on the number of cells per litre there was a significant removal of Chlorophyta in both types of CWs whereas there was no removal of Bacillariophyta and Cyanophyta (Table 6). There was a dominance of Chlorophyta in the system as they constituted 89-99\% of the total number of phytoplankton cells during the study.

Table 5

Species of algae found in the system with a fishpond and constructed wetlands for treatment of water.

\begin{tabular}{lll}
\hline Bacillariophyta & Chlorophyta & Cyanophyta \\
\hline Cymbella lanceolata & Ankistrodesmus falcatus & Anabaena circinalis \\
Cymbella targida & Arthrodesmus arcuatus & Aphanocapsa pulchra \\
Cymbella ventricosa & Asterococcus limneticus & Chroococcus giganteus \\
Gomphonema longiceps & Coelosphaerium \\
& javanicum & kutzingianum \\
Navicula gracilis & Chlorococcum humicola & Lyngbya contorta \\
Navicula lyra & Crucigenia rectangularis & Microcystis aeruginosa \\
Navicula placentula & Eudorina elegans & Oscillatoria formosa \\
Navicula placentula & Eudorina unicocca & Oscillatoria irrigua \\
fo. latiuscula & & \\
Nitzschia acicularis & Golenkinia paucispina & Oscillatoria limosa \\
Nitzschia longissima & Gonium pectorale & Phormidium moile \\
Nitzschia longissima & Kirchneriella lunaris & Trichodesmium lacustre \\
var. reversa & & \\
Synedra tabulata & Mougeotia scalaris & \\
Synedra ulna & Pandorina minodi & \\
& Planktosphaeria gelatinosa & \\
& Scenedesmus armatus & \\
& Scenedesmus ecornis & \\
& Scenedesmus dimorphus & \\
& Scenedesmus quadricauda & \\
& Sphaerocystis schroeteri & \\
& Staurastrum dejectum & \\
& Staurastrum natato & \\
& & \\
& &
\end{tabular}

Table 6

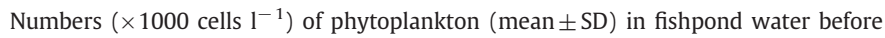
(In) and after treatment in constructed wetlands with horizontal flow (HF) or vertical flow (VF) and results of one-way ANOVA (F-Ratios).

\begin{tabular}{lcccl}
\hline & In & Out HF & Out VF & F-ratio \\
\hline Bacillariophyta & $18.4 \pm 7.8$ & $14.4 \pm 7.8$ & $13.5 \pm 4.0$ & $1.09^{\mathrm{NS}}$ \\
Chlorophyta & $3538 \pm 1040^{\mathrm{b}}$ & $2058 \pm 1382^{\mathrm{a}}$ & $2182 \pm 955^{\mathrm{a}}$ & $4.05^{*}$ \\
Cyanophyta & $118 \pm 67$ & $67 \pm 37$ & $70 \pm 37$ & $2.18^{\mathrm{NS}}$ \\
Total & $3675 \pm 1065^{\mathrm{b}}$ & $2139 \pm 1412^{\mathrm{a}}$ & $2265 \pm 966^{\mathrm{a}}$ & $4.19^{*}$ \\
\hline
\end{tabular}

Different letter superscripts between columns indicate significant difference. NS: not significant.

* $P<0.05$.

\section{Discussion}

The results of the study clearly show that fishpond water can be treated by recirculating the water through constructed wetland systems and the need for water renewal of the fishponds can thereby be reduced. The integrated fishpond and CW system, both in terms of water quality and fish and plant growth, was found to function well, with no discharge of water and low fish mortality during the study period. As the main part of the 4.5-month study period took place in the dry season, significant amounts of water was lost through evapotranspiration and replaced by tap water. Hence, in the dry season the system can be regarded as a zero-discharge recirculating system. But in the wet season it will probably be necessary to discharge water from the fishponds after heavy rainfalls.

The fishpond water was very dilute and contained low concentrations of BOD and nutrients, and therefore we applied very high HLRs to the CW systems. Despite the very high HLRs, the CW systems performed well, and we only observed problems with surface ponding and flow in one of the HFCWs at the highest HLR of $3000 \mathrm{~mm} \mathrm{~d}^{-1}$. The CW systems could however be improved by adding a settling tank and/or a sand filter before the CW units to prevent clogging of the gravel filter media by sludge and algae. In the VFCWs we did not observe any problems with clogging throughout the study.

The water quality in the fishpond remained acceptable for fish growth throughout the 4.5-month study with very low fish mortalities. The temperature in the fishpond was in the range 26.6$30.4^{\circ} \mathrm{C}$ which is suitable for warm water fish like tilapia and common carp. These fish species are relatively tolerant to poor water quality such as low DO and high TAN concentrations (Piedrahita, 2003). DO in the fishpond did fluctuate diurnally with lowest concentrations in the early morning and highest in the late afternoon because of photosynthetic algae, which produced oxygen during the day and consumed oxygen during the night. The fishpond water was in consequence supersaturated with DO in the middle of the day with concentrations up to $12-13 \mathrm{mg} \mathrm{l}^{-1}$, and had DO concentrations as low as $1 \mathrm{mg} \mathrm{l}^{-1}$ during the night. For tilapia the critical DO concentration where growth is affected by low DO more than food availability has been reported to be $1 \mathrm{mg} \mathrm{l}^{-1}$ (Yang, 1998). Therefore, the tilapia growth was probably not significantly affected by the low DO concentrations in the present study, but for more sensitive species the DO concentrations should be kept higher.

There was a good removal of organic matter measured as oxygen demand with up to $50 \%$ removal of BOD and COD in both types of CWs despite the high HLRs and the low concentration levels. In another study, where similar fishpond water was treated by a combination of a free water surface CW and a HFCW, the removal of COD was in the same range (25-55\%) but at significantly lower HLRs between 18 and $135 \mathrm{~mm} \mathrm{~d}^{-1}$ (Lin et al., 2002). In the present study, the removals of BOD and COD did not differ significantly between the CW types. It was expected, that the VFCWs would perform better than the HFCWs concerning removal of oxygen demand, because VFCWs are pulse-loaded and have unsaturated flow and consequently a higher transfer of oxygen to the filter medium compared to 
HFCWs (Kadlec and Wallace, 2008), but there was a significant difference in DO concentrations in the outlets. In the VFCWs, the outlet DO concentrations were in the range 5.3-6.1 $\mathrm{mg} \mathrm{l}^{-1}$, whereas in the HFCWs, the outlet DO concentrations were substantially lower than in the inlet. This difference was especially pronounced at the lowest HLR where the mean inlet DO in the HFCWs was $6.3 \mathrm{mg} \mathrm{l}^{-1}$ and the outlet DO was $2.3 \mathrm{mg} \mathrm{l}^{-1}$. This indicates that part of the oxygen used for degradation of organic matter (removal of BOD and COD) in HFCWs is taken from the water, whereas in VFCWs the oxygen transfer from the atmosphere into the unsaturated bed is more than adequate to meet the oxygen needs.

The TN outlet concentrations did not differ between the two types of CWs, but there was a significant effect of HLR as both inlet and outlet concentrations increased during the monitoring period. Actually, $\mathrm{N}$ was found mainly as organic $\mathrm{N}$ and accumulated in the water over time because of excreta from the fish, phytoplankton and uneaten feed. The $\mathrm{N}$ removal processes were hence not able to balance the input. There was, however, a significant difference in N processing between the $\mathrm{CW}$ types, as nitrification rates were much higher in VFCWs compared to HFCWs, which had almost no nitrification. In VFCWs, outlet concentrations of both $\mathrm{NO}_{2}^{-}$and $\mathrm{NO}_{3}^{-}$increased at higher HLR indicating a higher nitrification rate although the water actually had shorter retention time and therefore shorter contact time with the nitrifying bacteria in the $\mathrm{CW}$ bed. This indicates that the biofilm of bacteria responsible for nitrification was not fully developed at the beginning of the monitoring period (the lowest HLRs) although the system had been running for 3 months prior to the monitoring. Other studies have reported that it might take from a few months up to a year before the nitrogen processing biofilm is developed fully to provide stable outlet concentrations (Lin et al., 2002). Other possible explanations could be plant uptake of $\mathrm{NO}_{3}^{-}$during the early phase or that mineralization of organic $\mathrm{N}$ limited nitrification. The $\mathrm{NO}_{2}^{-}$concentrations were always $<0.07 \mathrm{mg} \mathrm{l}^{-1}$ and hence below the toxic limit of $0.5 \mathrm{mg} \mathrm{l}^{-1}$ in aquaculture systems (Al-Hafedh et al., 2003). While $\mathrm{NH}_{3} / \mathrm{NH}_{4}^{+}$and $\mathrm{NO}_{2}^{-}$are toxic to fish, $\mathrm{NO}_{3}^{-}$is relatively harmless, and in some recirculating aquaculture systems the concentrations can reach 300$400 \mathrm{mg} \mathrm{l}^{-1}$ without detrimental effects on the fish (van Rijn, 1996).

The higher nitrification rates in VFCWs also affected the TAN outlet concentrations which were lower in VFCWs compared to HFCWs. There was a net removal of TAN in VFCWs with the exception of the first trial at a HLR of $750 \mathrm{~mm} \mathrm{~d}^{-1}$, when mineralisation of organic $\mathrm{N}$ and nitrification seemed to be limited. In contrast, there was a constant production of TAN in HFCWs due to the mineralisation of organic $\mathrm{N}$ and low nitrification rates. The concentrations of TAN were fairly constant in the fishpond water and were below $1 \mathrm{mg} \mathrm{l}^{-1}$ throughout the study. At $\mathrm{pH} 7.0$, less than $1 \%$ of TAN is the toxic, un-ionized ammonia $\left(\mathrm{NH}_{3}\right)$, and it is reported that tilapia can tolerate $\mathrm{NH}_{3}$ concentrations up to $2 \mathrm{mg} \mathrm{l}^{-1}$ and common carp up to $1.7 \mathrm{mg} \mathrm{l} \mathrm{I}^{-1}$. The $\mathrm{NH}_{3}$ concentrations in the present study were thus not critical for the fish (Stickney, 2000; Ridha and Cruz, 2001).

Concentrations of TP and $\mathrm{PO}_{4}^{3-}$ in the water increased steadily during the study period as P was barely removed in the CWs. Normally, P is not regarded critical for fish growth as it is not toxic at the concentrations generally found in aquaculture. But high concentrations can cause algal blooms. If a substantial and constant removal is wanted, the best solution is probably to install a unit with P-adsorbing substrate (Naylor et al., 2003) or to use chemical precipitation.

The Canna $\times$ generalis grew well throughout the study in both types of CWs. However, plants in the VFCWs grew faster and had higher tissue concentrations of $\mathrm{N}$ and $\mathrm{K}$ in aboveground biomass compared to plants in the HFCWs. This could be due to the different oxygen conditions in the two systems as the VFCWs had significantly higher DO outlet concentrations than the HFCWs. The lower growth rates of plants in the HFCWs could be caused by the constant flooded and hence low oxygen conditions in the HFCWs as has also been shown in other studies with comparisons of flooded and non-flooded plants (Pezeshki, 2001;
Chen et al., 2005). It has been shown that Canna indica is indifferent to $\mathrm{N}$ form and can use both $\mathrm{NH}_{4}^{+}$and $\mathrm{NO}_{3}^{-}$as $\mathrm{N}$ source under oxic conditions (Konnerup and Brix, 2010). However, it is possible that the hypoxic conditions in HFCWs might impede uptake of $\mathrm{N}$ and other elements since uptake mechanisms require energy from respiration. An option could be to use other tropical wetland plant species like e.g. Eleocharis dulcis and Phragmites vallatoria which are more adapted to anoxic conditions because they have the ability to produce an internal pressure and a convective gas flow through the rhizomes. This is an adaption to wetland conditions and gives a better aeration of the belowground plant parts (Konnerup et al., in press). However, these plants have lower aesthetic value and may therefore not be as attractive as Canna spp. The amounts of nutrients that could be removed via harvest of the aboveground biomass were 0.38 and $0.97 \mathrm{~g} \mathrm{~N} \mathrm{~m}^{-2} \mathrm{~d}^{-1}$ and 0.098 and $0.215 \mathrm{~g} \mathrm{P} \mathrm{m}^{-2} \mathrm{~d}^{-1}$, for HFCWs and VFCWs, respectively. If the system was scaled up to a larger size these values might be lower as the vegetation was very dense at the end of the study period and edge effects were significant. However, in a full scale system where plants might be harvested on a regular basis it would be possible to keep the plants in the exponential growth phase where removal via harvest is highest. The plant uptake in aboveground biomass during the study period, and hence the amount of nutrients that could be removed by plant harvest, constituted $8.2 \%$ and $7.9 \%$ of the fish feed input of $\mathrm{N}$ and $\mathrm{P}$, respectively.

The fish in the pond had a FCR of 1.53 based on feed dry weight and an efficient incorporation of $\mathrm{N}$ and $\mathrm{P}$ from the feed into fish biomass with nutrient conversion rates of $31.4 \%$ and $33.6 \%$, respectively. This is slightly better than tilapia FCRs in the range 1.61-2.04 obtained in other studies (Ridha and Cruz, 2001; Shnel et al., 2002; Al-Hafedh et al., 2003). Maybe the fish in the fishpond were also feeding on algae and thus had an additional food source with reuse of nutrients. The nutrient conversion rates for $\mathrm{N}$ and $\mathrm{P}$ in the present study were comparable with those of $32.5 \%$ and $16.0 \%$ reported by Rafiee and Saad (2005) and 36.4\% and 45.5\% reported by Lin and Yi (2003).

Forty five different species of algae were identified in the system and they probably also served as an additional food source for the fish as both tilapia and common carp are known to feed on algae (Turker et al., 2003a; Rahman et al., 2006). Common carp only feed on algae to a minor degree and prefers artificial feed, macroinvertebrates and zooplankton, if available (Rahman et al., 2009). In contrast, tilapia which constituted the main part of the fish population in the present study, have been reported to be able to control algae biomass in ponds by efficient grazing (Rahman et al., 2008). Among the algae found in the fishpond, several species that can potentially be harmful by producing toxins were identified. Microcystins are considered as a dangerous group of cyanotoxins that can be produced by several genera of cyanobacteria such as Anabaena, Nostoc, Oscillatoria, Nodularia and mainly Microcystis (Prieto et al., 2007). Some of these (Anabaena, Oscillatoria and Microcystis) were observed in the fishpond but were not dominant and did probably not affect the fish. Other studies report that Nile tilapia prefers to feed on cyanobacteria and can change the composition of the phytoplankton community. Comparing aquaculture system with and without Nile tilapia, it has been found that systems without tilapia in general have higher densities of algae and 2-3 times more cyanobacteria than systems with tilapia (Turker et al., 2003a). Nile tilapia may also significantly reduce the abundance of the cyanobacterium Microcystis and the green algae Scenedesmus which were also present in this study (Turker et al., 2003b). After gut passage of Nile tilapia the photosynthetic activity of Microcystis spp. has been reported to be reduced by $92-95 \%$ whereas gut passage of silver carp (Hypophthalmichthys molitrix) stimulated the photosynthetic activity (Jancula et al., 2008). This demonstrates that tilapia has an ability to digest cyanobacteria. We did not observe Microcystis during the last 8 weeks of the trials, maybe because the tilapia population had reached a capacity to control Microcystis by grazing. The temperatures in this study were also suitable for tilapia grazing as it has been reported that tilapia has a significantly 
higher filtration rate of phytoplankton in warm water $\left(26-32^{\circ} \mathrm{C}\right)$ compared to colder water $\left(17-23^{\circ} \mathrm{C}\right)$ (Turker et al., 2003c).

\section{Conclusion}

This study demonstrated that CWs have great potential for treatment of fishpond water in recirculating aquaculture systems in Vietnam. During the 4.5 month experimental period no water was discharged from the fishpond to the environment. As the study was conducted in the dry season, water actually had to be added to the fishpond to compensate for the evaporative loss. In the wet season, it will probably be necessary to discharge excess water from the fishpond system, but the discharge will be much less than from traditionally practised fishponds where large amounts of water are exchanged frequently throughout the year to maintain an adequate water quality in the ponds. Vertical flow CWs seem to be particularly useful as they have higher nitrification rates and higher DO concentrations in outlets, and the plants also grew faster and took up more nutrients in VFCWs than in the HFCWs. Since oxygenation of the water is an important parameter for optimal fish growth, it is recommended to have a high recirculation rate and this study showed that it is possible to apply a HLR of $3000 \mathrm{~mm} \mathrm{~d}^{-1}$ to the VFCWs without clogging. Another option could be to apply lower HLRs and to have a larger CW area per fishpond area which would also make it possible to obtain a higher recovery of nutrients from the fishpond in plant biomass. The economic consequences of integrating CW systems into recirculating aquaculture systems in Vietnam and elsewhere remains to be resolved, as do the long-term performance and sustainability of the systems.

\section{Acknowledgements}

This project was financially supported by the Danish International Development Agency (DANIDA) and the Danish Natural Science Research Council and by travel grants from Cowi, Oticon and Grontmij | Carl Bro.

\section{References}

Al-Hafedh, Y.S., Alam, A., Alam, M.A., 2003. Performance of plastic biofilter media with different configuration in a water recirculation system for the culture of Nile tilapia (Oreochromis niloticus). Aquacult. Eng. 29, 139-154.

APHA, 1998. Standard Methods for Examination of Water and Wastewater. American Public Health Association, Washington DC.

Brix, H., 1997. Do macrophytes play a role in constructed treatment wetlands? Water Sci. Technol. 35, 11-17.

Brix, H., Koottatep, T., Laugesen, C.H., 2007. Wastewater treatment in tsunami affected areas of Thailand by constructed wetlands. Water Sci. Technol. 56, 69-74.

Cabello, F.C., 2006. Heavy use of prophylactic antibiotics in aquaculture: a growing problem for human and animal health and for the environment. Environ. Microbiol. 8, 1137-1144.

Chen, H.J., Qualls, R.G., Blank, R.R., 2005. Effect of soil flooding on photosynthesis, carbohydrate partitioning and nutrient uptake in the invasive exotic Lepidium latifolium. Aquat. Bot. 82, 250-268.

Dan, T.H., Quang, L.N., Chiem, N.H., Brix, H., in press. Treatment of high-strength wastewater in tropical constructed wetlands planted with Sesbania sesban: Horizontal subsurface flow versus vertical downflow. Ecol. Eng. doi:10.1016/j. ecoleng.2010.07.030.

Jancula, D., Mikovcova, M., Adamek, Z., Marsalek, B., 2008. Changes in the photosynthetic activity of Microcystis colonies after gut passage through Nile tilapia (Oreochromis niloticus) and silver carp (Hypophthalmichthys molitrix). Aquac. Res. 39, 311-314.

Kadlec, R.H., Wallace, S.D., 2008. Treatment Wetlands. CRC Press, Boca Raton, FL.

Konnerup, D., Brix, H., 2010. Nitrogen nutrition of Canna indica: effects of ammonium versus nitrate on growth, biomass allocation, photosynthesis, nitrate reductase activity and $\mathrm{N}$ uptake rates. Aquat. Bot. 92, 142-148.
Konnerup, D., Koottatep, T., Brix, H., 2009. Treatment of domestic wastewater in tropical, subsurface flow constructed wetlands planted with Canna and Heliconia. Ecol. Eng. 35, 248-257.

Konnerup, D., Sorrell, B.K., Brix, H., in press. Do tropical wetland plants possess convective gas flow mechanisms? New Phytol. doi:10.1111/j.1469-8137.2010.03585.x.

Le, T.X., Munekage, Y., 2004. Residues of selected antibiotics in water and mud from shrimp ponds in mangrove areas in Viet Nam. Mar. Pollut. Bull. 49, 922-929.

Lin, C.K., Yi, Y., 2003. Minimizing environmental impacts of freshwater aquaculture and reuse of pond effluents and mud. Aquaculture 226, 57-68.

Lin, Y.F., Jing, S.R., Lee, D.Y., Wang, T.W., 2002. Nutrient removal from aquaculture wastewater using a constructed wetlands system. Aquaculture 209, 169-184.

Naylor, S., Brisson, J., Labelle, M.A., Drizo, A., Comeau, Y., 2003. Treatment of freshwater fish farm effluent using constructed wetlands: the role of plants and substrate. Water Sci. Technol. 48, 215-222.

Nhan, D.K., Phong, L.T., Verdegem, M.J.C., Duong, L.T., Bosma, R.H., Little, D.C., 2007. Integrated freshwater aquaculture, crop and livestock production in the Mekong delta, Vietnam: determinants and the role of the pond. Agric. Syst. 94, 445-458.

Nhan, D.K., Verdegem, M.C.J., Milstein, A., Verreth, J.A.V., 2008. Water and nutrient budgets of ponds in integrated agriculture-aquaculture systems in the Mekong Delta, Vietnam. Aquacult. Res. 39, 1216-1228.

Pezeshki, S.R., 2001. Wetland plant responses to soil flooding. Environ. Exp. Bot. 46, 299-312.

Phan, L.T., Bui, T.M., Nguyen, T.T.T., Gooley, G.J., Ingram, B.A., Nguyen, H.V., Nguyen, P.T. De Silva, S.S., 2009. Current status of farming practices of striped catfish, Pangasianodon hypophthalmus in the Mekong Delta, Vietnam. Aquaculture 296, 227-236.

Piedrahita, R.H., 2003. Reducing the potential environmental impact of tank aquaculture effluents through intensification and recirculation. Aquaculture 226 35-44.

Prieto, A.I., Pichardo, S., Jos, A., Moreno, I., Camean, A.M., 2007. Time-dependent oxidative stress responses after acute exposure to toxic cyanobacterial cells containing microcystins in tilapia fish (Oreochromis niloticus) under laboratory conditions. Aquat. Toxicol. 84, 337-345.

Rafiee, G., Saad, C.R., 2005. Nutrient cycle and sludge production during different stages of red tilapia (Oreochromis sp.) growth in a recirculating aquaculture system. Aquaculture 244, 109-118.

Rahman, M.M., Hossain, M.Y., Jo, Q., Kim, S.K., Ohtomi, J., Meyer, C., 2009. Ontogenetic shift in dietary preference and low dietary overlap in rohu (Labeo rohita) and common carp (Cyprinus carpio) in semi-intensive polyculture ponds. Ichthyol. Res. 56, 28-36.

Rahman, M.M., Verdegem, M., Wahab, M.A., 2008. Effects of tilapia (Oreochromis niloticus L.) stocking and artificial feeding on water quality and production in rohucommon carp bi-culture ponds. Aquac. Res. 39, 1579-1587.

Rahman, M.M., Verdegem, M.C.J., Nagelkerke, L.A.J., Wahab, M.A., Milstein, A., Verreth, J.A.J., 2006. Growth, production and food preference of rohu Labeo rohita (H.) in monoculture and in polyculture with common carp Cyprinus carpio (L.) under fed and non-fed ponds. Aquaculture 257, 359-372.

Ridha, M.T., Cruz, E.M., 2001. Effect of biofilter media on water quality and biological performance of the Nile tilapia Oreochromis niloticus L. reared in a simple recirculating system. Aquacult. Eng. 24, 157-166.

Shnel, N., Barak, Y., Ezer, T., Dafni, Z., van Rijn, J., 2002. Design and performance of a zero-discharge tilapia recirculating system. Aquacult. Eng. 26, 191-203.

Spencer, D.F., Liow, P.S., Chan, W.K., Ksander, G.G., Getsinger, K.D., 2006. Estimating Arundo donax shoot biomass. Aquat. Bot. 84, 272-276.

Stickney, R.R., 2000. Encyclopedia of Aquaculture. John Wiley \& Sons, Inc., New York.

Tilley, D.R., Badrinarayanan, H., Rosati, R., Son, J., 2002. Constructed wetlands as recirculation filters in large-scale shrimp aquaculture. Aquacult. Eng. 26, 81-109.

Trang, N.T.D., Konnerup, D., Schierup, H.H., Chiem, N.H., Tuan, L.A., Brix, H., 2010. Kinetics of pollutant removal from domestic wastewater in a tropical horizontal subsurface flow constructed wetland system: effects of hydraulic loading rate. Ecol. Eng. 36, 527-535.

Turker, H., Eversole, A.G., Brune, D.E., 2003a. Filtration of green algae and cyanobacteria by Nile tilapia, Oreochromis niloticus, in the partitioned aquaculture system. Aquaculture 215, 93-101.

Turker, H., Eversole, A.G., Brune, D.E., 2003b. Effect of Nile tilapia, Oreochromis niloticus (L.), size on phytoplankton filtration rate. Aquac. Res. 34, 1087-1091.

Turker, H., Eversole, A.G., Brune, D.E., 2003c. Effect of temperature and phytoplankton concentration on Nile tilapia Oreochromis niloticus (L.) filtration rate. Aquac. Res. 34, 453-459.

van Rijn, J., 1996. The potential for integrated biological treatment systems in recirculating fish culture - a review. Aquaculture 139, 181-201.

Yang, Y., 1998. A bioenergetics growth model for Nile tilapia (Oreochromis niloticus) based on limiting nutrients and fish standing crop in fertilized ponds. Aquacult. Eng. 18, 157-173.

Zurita, F., De Anda, J., Belmont, M.A., 2009. Treatment of domestic wastewater and production of commercial flowers in vertical and horizontal subsurface-flow constructed wetlands. Ecol. Eng. 35, 861-869. 